\title{
Not saving or psychology, or science, but a new liberalism: a reply to Gaus, Goldstone, Baker, Amadae, and Mokyr
}

\author{
DEIRDRE NANSEN MCCLOSKEY \\ University of Illinois
}

\begin{abstract}
The reply to five reviews of Bourgeois equality in a symposium in EJPE observes that all the reviewers admit the great force of ideas in causing the Great Enrichment. Materialism is dead. Liberalism reigns.
\end{abstract}

Well, a philosopher, a sociologist, another philosopher, a political theorist, and an economic historian. This is going to be interesting!

Gerald Gaus' over-generous praise startles me-I didn't set out to write a "great work", and am reluctant to think it is anything close (I blush). I merely intended in the trilogy of The bourgeois virtues: ethics for an age of commerce (2006), Bourgeois dignity: why economics does not explain the modern world (2010), and the present volume to redeem the bourgeoisie and to find out the scientific truth about its role in making the modern world. I thought the job would take one volume. In the end it took some 1,700 pages. The main reason I stopped at three volumes-the present, third volume being even longer than the other two stouts-was articulated by the philosopher of religion Alvin Plantinga justifying stopping at his own third volume, on warranted belief: "A trilogy is perhaps unduly self-indulgent, but a tetralogy [not to speak of the hexology I once contemplated] is unforgivable" $\left(2000\right.$, xiv). ${ }^{1}$

You don't write some 1,700 pages of evidence and reasoning about history and economics and ethics and the rest as though writing a bank draft (to quote the young Kant), with a pre-planned and routine outcome. The experience is less like central planning and more like trade-tested betterment. Over the twenty years of thinking and reading, among which the twelve years of writing, I hope I made a few

\footnotetext{
${ }^{1}$ I have in the past, without properly checking the source, improved on his remark by remembering it as "but a tetralogy is an abomination". Thus scribal error.
} 
discoveries. The chief discovery, I fancy, is that the one essential cause of the modern world, "the central pole of the tent", in the old figure of speech, a cause much more important than any psychological change in the direction of better bourgeois behavior (of the sort Max Weber imagined in 1905), was the sociological and political change unique to northwestern Europe of accepting the bourgeoisie and its fruits. The change in the ideology surrounding ordinary people, allowing them to have a go-"the liberal plan of equality, liberty, and justice", as the blessed Adam Smith put it-made people bold (1981 [1776], bk. IV, chap. 9, para. 3). ${ }^{2}$ And inventive. And rich. And cultivated. Thus Bourgeois equality: how ideas, not capital or institutions, enriched the world.

Yet Gerry Gaus, when he hears John W. Chapman speak out loud and bold, says that I didn't "get it entirely right". His theme is that I am insufficiently game-theoretic and institutional, missing my own best point. He asserts, against what he thinks is my (1905 Weberian, psychological, Die protestantische Ethik und der Geist des Kapitalismus) point, that "there is strong reason to question the explanatory power of character traits and attitudes".

Yet on the contrary I am saying that it was not the character traits of the bourgeois, but the ideology of those around them that changed (or if you want a word that Marx did not invent, it's the social rhetoric that changed; or if you wish a less contentious word, the social ethics).

Gerry's misunderstanding is surprising coming from someone who never in my experience makes mistakes in such matters. He must have started from some strong prior conviction, which makes it hard for him to discern the present point. What prior? Hmm. He thinks my main opponent is the late lamented Douglass North and his neo-institutional followers. I admit to arguing against Doug in this volume, and in Bourgeois dignity and in other essays (McCloskey 2010, chaps. 33-36; 2016a, chaps. 14-15; 2013; 2014a; 2016c; 2016d). But Gaus thinks I am fooling myself by opposing Doug. He wants me to recover North's focus on "the institutional rules of the game", by way of Bicchieri's gametheoretic logic, "the rule-governance of social morality". He's slouching towards North. And anyway he's slouching towards an economistic line of argument that notably neglects the autonomous role of ideas.

\footnotetext{
${ }^{2}$ Smith is here attacking Colbert and mercantilism. Speaking of scribal error, I often get wrong the order Smith gave to the three attributes of an unplanned plan of "allowing every man to pursue his own interest in his own way".
} 
Economism of course has some merit-I do not want my union card as an economist, Harvard Local 02136 and Chicago Local 60637-to be taken away. But game theory is something like the opposite of what I came to argue. Another way to understand the three volumes is the working out in ethics and history and sociology and literature of an escape from the Prudence Only character that lies at the heart of Samuelsonian economics. Despite Doug North's protestations, he and his followers espouse a highly conventional Prudence Only, materialist, Max U, "neoclassical", non-cooperative-game-theory notion of people and societies. I wish they wouldn't. I wish they would grow up and notice that people think and love and argue. It's the force of language. As Smith said, "every one is practicing oratory on others thro the whole of his life" (1978 [1762-1766], LJA, vi.56, 352).

Gaus declares that "modern ethics concerns what we must do-what we are required to do even if we are not attracted to it". Shades of Kant and deontology. No rhetoric, no oratory, no ideas, no ideology, thank you very much: we are Scientists of society, and don't deal with such softness. Gaus wants there to be rigid rules, and he wants them to have a no-talk, game-theoretic support. Thus North again, and Avner Greif (2006). "Does [a good person] ascribe to bourgeois virtue? [Note again that he thinks it is the behavior of the bourgeoisie I am talking about, instead of how others value it.] I don't know. Must she act in the required way? Certainly". This is Kant indeed, the attempt to build ethics on what every rational actor must ascribe to. Sie müssen.

In the words of an old New Yorker cartoon showing a child kicking at dinner in a high chair: I say it's spinach, and I say to hell with it.

Though I admire his philosophical history of hunter-gathering, and rely on it in the present book, Gaus is not a particularly historical thinker. That's all right. One can't do everything. It's good to hear for example about the experiment, co-authored with Shaun Nichols, showing that "a social morality that stresses [minimally just] prohibitions rather than [pre-arranged, hierarchically granted] permissions encourages innovation and exploratory action". It's an interesting result. And of course, as I said in the book, the same observation about behavior is typical of Hume and Smith and Kant and one side of Aufklärung. It is liberal ideology, by contrast with Colbert's mercantilism.

I do wish Gaus would realize, though, that we need to solve a historical as much as an economic problem, namely, why the Great 
Enrichment happened when and where it did, in a bit of northwestern Europe in the past two or three centuries. The purely economic arguments, as I showed at some length, especially in the previous volume, Bourgeois dignity, have this problem: that China, for example, had coal and India a massive foreign trade and Spain a great overseas empire and the Ottomans the rule of law and France an Enlightenment, yet none initiated the Great Enrichment.

That's the trouble with timeless arguments from game theory, such as Bicchieri's, or North's, or Acemoglu's. In one sense they explain too much, because their mechanisms are universal. In another sense they explain too little, because they do not attend to the ideational peculiarity of the Dutch and English bits of northwestern Europe (namely, the peculiarity of a nascent liberalism). Gaus notes that "in the last fifteen years a large body of evidence has accumulated that the actions of humans are critically sensitive to the normative expectations of others". Aside from noting with some annoyance that we hardly need evidence from "the last fifteen years" for such an ancient and obvious feature of human nature (Antigone? The Hebrew Prophets? The Mahabharata?), I entirely agree. And it is a quite different notion than the Better Bourgeois that Gaus thinks I am claiming. "The critical point is that ['trendsetters', in Bicchieri's vocabulary] were able to shape the social rules that generated normative expectations supporting equal dignity, liberty, markets and innovation, and that these normative expectations were widely accepted as legitimate". Sure.

All right, but then why then and there? That's the historico-scientific puzzle. The Bicchierian logic would apply to the Roman Republic or to early modern Japan, which didn't produce the modern world. My book tries to explain why then and there, first in Holland and then in Britain, and finds that it was a close thing, but decidedly ideological, a matter of ideas, which of course themselves had causes, some of them material (European 'discovery' of the New World, European orientation towards the sea, European political fragmentation) but many of them ideational (the Reformation, science, the rights of man). Gaus declares that "A framework of liberal equality embraces this ideal of universal membership in the community: the rules of basic social life apply equally to all, simply as members of a community". But that's the liberal ideology on which I put so much emphasis (wholly justified, natch).

"The moral rules of the game", writes Gaus, channeling North again, "[obtain] when we confront total strangers. In most cases we know little 
about these strangers-in particular, their conception of virtue and how well they live up to what they consider virtuous-yet we need to rely on them. How can that happen"?

It happened anciently. It is not true that there was an internal, psychological "development" of honesty, for example. There was in northwestern Europe a new public honoring of commercial honesty, which is an entirely different matter, a matter of ideology or rhetoric or ethics, taking place historically and sociologically, not economically and psychologically.

Aside from these textual matters, I must say I find myself repelled by Gaus' vision of people as cynical conformists: "we are such deeply social normative creatures, in the sense that we are so attuned to the normative expectations of others, that we can achieve a stable rulebased system of cooperation even when many are not enthusiastic about the moral attitudes and virtues that the rules express". I invite him to re-read Thucydides' dialogue between the Athenian diplomats and the Melians, and repent. " A critical explanatory variable for many people", Gaus writes, "is their responsiveness to the normative expectations of those with whom they share a social life". I agree, and said so repeatedly, though not on the basis of game theory construed as a complete social science (as my friendly acquaintances Gintis and Bowles, admired by Gaus, do so try to construe it). "I believe that it is, in general, false that everyday moral action requires virtues such as temperance or courage, or even the 'middling' virtues, except in so far as one must be sensitive to the legitimate expectations of others". This other-directed, contemporaneous (as against, say, the developmental story of Confucius or Adam Smith), Nash-equilibrium concept of 'virtue' is a strange characterization of most of the beautiful minds I know, including that of Gerald Gaus. The courageous pursuit of truth that characterizes his work, for example, would be reduced in his theory to conformist careerism. "We should never underestimate just how important conformity is to any culture". So Gerry evidently believes, at any rate when he is thinking theoretically. "Most, I think, seem essentially driven by what they expect others will do, and what they believe are the legitimate normative expectations of others". This, I have to say, is nuts. Or spinach.

Although I admit that the economist in me delights in Gaus/ North / Bicchieri / Acemoglu / Gintis games. And I like spinach.

\footnotetext{
${ }^{3}$ The passage is brilliantly analyzed in White (1984).
} 
I can't possibly claim that Jack Goldstone misunderstands the book. His lucid and elegant summary deserves some sort of prize for scholarly temperance. The economist George Stigler once joked that John Stuart Mill was the only student of the economy to try the experiment of being completely fair to his opponents. The experiment, George continued, was never repeated. Except by the historical sociologist of the economy Goldstone, summarizing my argument:

What can prevent the elite from preventing change, when the status quo so strongly favors their interests? An insistence that ordinary people should be encouraged to act independently, be respected for originality and innovation, and be allowed to retain (most of) the profits of any activities they offer in free and fair markets.

Spot on.

Yet Jack doubts, with Gaus, that I have got it entirely right. "Why did the shift in rhetoric to value the bourgeoisie in England not simply evolve as it did in all other cases, namely to create an oligarchy of privileged merchants who still derided ordinary citizens"? It's an important question, to which I offered in the book in various places only a sketch of a reply, referring for example to the accidents following on the struggle between Stuarts and Parliament, 1625 to 1688, with a thoroughly bourgeois example of the Dutch Republic at hand. Had Charles I and especially James II not been so similar to their father and grandfather, James VI of Scotland and James I of England, "the wisest fool in Christendom", it might have turned out differently.

The other doubt is more fundamental. Jack asks, "How does anyone acquire the belief-based on no prior successful examples in historythat the best way to innovate is to perform thousands of experiments to create new products or processes as Wedgewood did to create Jasper blue (as McCloskey points out on page 522)"? He argues therefore that "it could not just have been respect that produced their extraordinarily productive innovations. Something else must have happened as well", in particular the new engineering culture that Goldstone and Joel Mokyr and Margaret Jacob have emphasized as special to the Europe of the Scientific Revolution and the Enlightenment. The point persuades, though one wonders at the implicit claim that an obsession with experiment did not also characterize many people in other cultures 
(Mayan? Chinese? Byzantine?) whose scientific culture we happen now to know less about.

But wait. Goldstone's first doubt concerning my argument was that the elite would usually stop progress, yet didn't in Britain. But the Bourgeois Revaluation which the book touts did in fact reverse such an ideology of protection, replacing it with an ideology of liberalism. We need to look into how and why it happened. Yet that is what the book does. To the correct observation that Britain is just where the elite did not stop progress, the book notes (pp. 629-630, but in numerous other places as well) that an engineering culture has to have a mass of innovators, a few of whom rise to the eminence of Newcomen, Smeaton, and Cartwright. Mass innovation requires exactly liberalism as a primary cause, allowing ordinary people to have a go. Si non, non. Or more to the point, if not, then not a vibrant Anglosphere but instead a stagnant Italy or France or even (by the 18th century) Holland, all of which had had vibrant scientific and engineering cultures.

"Why not a host of linked changes, to ideas, institutions, and capital", asks Goldstone, "that created a virtuous circle of crossfertilization without a single primary cause"? I often get the question why I focus on "a single primary cause", to which I reply that in science we are seeking such causes, and if one, or two, or three pretty much suffices, we say so. Because Coulomb's Law implies that the repulsions between positively charged but not massive spheres close to each other are very much stronger than their gravitational attraction, one can ignore the very small offsetting gravitational attraction in calculating the acceleration of the spheres away from each other. I showed in 2010 in Bourgeois dignity that the others and materialist explanations of the Great Enrichment, such as institutions and capital, don't work. They were dependent on liberalism or not necessary or had little economic oomph or occurred in various other parts of Eurasia also with suitable "horizontal conditions" (as Nancy Cartwright and Jeremy Hardie put it in their fine application of Cartwright's philosophy of causation [2012, e.g., p. 100]). So we are left with one cause, peculiar to northwestern Europe and especially, by an accident fortunate for we Anglophones, Britain, namely, liberalism.

Jack quarrels with my quarrel with neo-institutionalists such as North and Acemoglu, or in some of their moods Goldstone and Mokyr. He writes, "Institutions are simply ideas of proper behavior that have been codified by law or custom to become normative behavior. If ideas 
for what is proper normative behavior undergo a major alteration, then institutions should change as well". His remark well illustrates one of my objections to neo-institutionalism, namely, that it depends on a tautology. Let us define "institutions", Jack avers, as anything that comes out of human minds. Then we can drop changes of minds tout court as causal, since all changes in ideas must be codified as normative in what we are calling "institutions". So much for the idea of liberalism as causal. QED.

The tautology enables a good deal of hand-waving assertions of causality in neo-institutional circles. In Jack's case, for example, he vaunts the "the founding of the American colonies, and major victories over Spain and France [not finally, actually, until 18 June 1815] that shifted the balance of power in Europe and established Britain as a major power" as evidence that "it is hard to argue that Britain thus had no significant or rapid institutional changes prior to the "Great Enrichment'”. Well. It needs to be explained why the theme of "power and plenty", such as Ronald Findlay and Kevin H. O'Rourke (2007) put forward in an ill-considered book, and which power-politics theorists thrill to monthly in the pages of Foreign Affairs, is anything but a category mistake. Being powerful does not make you rich, unless violence against others is enriching. It's hasn't been much enriching in the dramatically positive-sum world since 1800 , and in truth was not much even in the old zero-sum world. Conquest is not a good business plan. Ask the Spaniards in the seventeenth century or the Russians now.

Another case of the magic of tautology is the assertion by numerous economic historians that the Dutch-inspired national debt-which allowed King Billy and Queen Anne then the Hanoverians depending, as Jack notes, on Parliament men to wage almost incessant war against Spain and France-made for a capital market. It has never been explained why the issuing of bonds to finance the throwing away of resources in pointless warfare did anything but crowd out civilian investment. The line of argument is: first call warfare or the national debt an "institution", then apply the tautological lemma, and conclude triumphantly that institutions "matter" without having to get into the irritating weeds of economic logic or measurement, not to speak of the development of actual ideas.

But Goldstone is better than this. I have always admired his precision in the use of historical examples, as in his riff here on the Scientific Revolution. He shares with Joel Mokyr, for instance, the 
conviction that "by the time of Francis Bacon, it was possible to conceive of a future in which mankind had amassed more and more valuable and powerful information than ever before". Surely he and Joel are right, although (to repeat) it needs to be acknowledged that we do not at present know enough about science and intellectual life in other places to be entirely sure that the down-playing of tradition was unique to Europe. The experience over the past few decades of having to radically revise the history of Chinese science and technology after Joseph Needham should make us a little cautious about accepting European superiority without enough actual knowledge about the non-Europeans. And anyway, if we suppose that "it was possible to conceive" of progress, are we not then dealing with an ideological change, not an institutional one (at any rate in a non-tautological sense)? I think Jack and Joel would agree. The extant institutions, after all, such as the Church or the monarchies or the older universities, fought the idea of progress to the death. Their death.

A big, big evidential problem with the emphasis by Goldstone, Mokyr, and Jacob on the Scientific Revolution and the Enlightenment is that these were Europe-wide, not special to Britain. Galileo and Catherine the Great, after all, were not British. Yet the Great Enrichment down to 1851 certainly overwhelming was. One must wonder why the Continent, which surely had an Enlightenment, did not therefore have a widespread Industrial Revolution (I use 'Continent' in the British sense: "Fog in Channel, Continent cut off").

Before 1851, Goldstone notes, "the gains in science had the impact of inspiring a desire for innovation and providing methods for its realization, but not yet of offering discoveries that would transform economies". I quite agree. Against Mokyr, I would date the economically weighty triumphs of Science to the 20th century. Before that: inspiration, yes; economically large impact, no. And even the inspiration and later the impact depended on a massive extension of "having a go", itself dependent on liberalism, or at any rate (to speak of chairs in chemistry in German universities) an egalitarian policy imposed by tyrants, itself inspired, as Jack says in his peroration, by ideas.

I emphasize liberalism, which has been set aside by most students of the matter since the 1890s, when historical materialism first captured the mind of Europe. In the end I think Jack would agree. 
But if Goldstone deserves a silver medal for accurate reading of what I wrote, Jennifer Baker gets the gold. I've dabbled in philosophy, most explicitly in Knowledge and persuasion in economics (1994b). But I know very well that I am a rank amateur compared with the genuine philosophers I've known moderately well, such as Bill Hart, John Nelson, Uskali Mäki, Jack Vromen, Richard Rorty, David Schmidtz, or Sam Fleischacker. What regularly astonishes me about philosophers, whether analytic or continental, is their ability to make distinctions, often important distinctions. 'Analysis' comes from Greek "cut apart". The cutting apart makes possible some important distinctions. Baker neatly cuts apart, for example, my argument into nine "implausible assumptions the [hypothesis of the Bourgeois] Deal avoids".

Her own project here is to ask "how to think about the 'haves' when you are a 'have not', which, she says (pretty much correctly) "is missing in McCloskey's approach". "Non-bourgeois values amount to a rather intact philosophical outlook". Agreed, they do, and keep surfacing (as in Donald Trump's views on foreign trade), which is one reason I wrote the trilogy.

"I do not know how McCloskey would write for this audience" of have nots. I admit that I'm writing mainly to the clerisy (get over your hatred of the bourgeoisie) and to the bourgeoisie itself (stop apologizing). But I could write to the poor, too, and, as she suggests, I should. After all, I got into economics and stayed in it to help the poor, and all our honored ancestors, among them mine, were poor, and I've known actual poor people all my life, some of them pretty well. "The unequal distribution of the goods of this world' is considered to be efficacious for reasons mere humans cannot access is a very particular viewpoint, particularly supportive of trade-tested betterment". Yes, it is a view particular to a modern view of economics, Schumpeterian, even. You see it even in Rawls. It doesn't much appeal to actual poor people, only to their soi-disant defenders from the right or from the left.

But that is why we need, in getting the poor onto the program, an ideology supporting what Hayek dubbed the Great Society. Demonstration effects, such as the utter collapse of the Venezuelan economy recently, or the startling enrichment since 1978 of coastal China, or the American Dream fulfilled even now by many Americans, do support the faithful bourgeois ideology. But, St. Paul observed, "faith 
is assurance of things hoped for, a conviction of things not seen". Keep the faith. It's hard. After every major financial crash, the worst being after 1929, but now again a pretty bad one after 2007, the fragile faith in what I called the Bourgeois Deal-that "very particular viewpoint"-is challenged, occasionally from the working class itself, and always since 1848 , from the left clerisy helpfully telling the working class what to think about the terrible problems of markets, bankers, alienation, inequality, and the lack of jobs for the clerisy to administer the sadly imperfect economy.

Baker thinks there is a problem of the have nots perceiving the demonstrations of the 'particular viewpoint' that seem so obvious to her and me. "If the horrors of present-day Venezuela are used to convince low wage workers that the Deal we have is fair, it is still the case that low wage workers have less to lose in such a transition". I think I see her point. People think La Revolución will make them better off. I remember thinking it myself, back in 1960 when I agreed with Bernie Sanders on every point (we didn't know each other, but were ignorant radicals together; the difference is that since 1960 I have continued thinking it through). But in fact La Revolución only does so relatively, by equalizing misery. Hang the bankers from the lampposts, invade the houses of the rich. And end up as poor as Cuba, in which real income has not risen since 1959. (Yet Baker is right that a few of the have nots, and most of the left clerisy, still think that Cuba is a workers' paradise.)

My claim, and in the end I think Baker's, too, is that philosophy in such matters should be, as Dick Rorty used to say, edifying, persuading people to the good life, and not accepting their sin of envy as a given preference of Max U to be honored. "I do not see that McCloskey has yet confronted a non-elite, non-bourgeois ethos as if it had normative content at odds with the terms of the original [Bourgeois] Deal". True. But our task is edification, that is, changing the minds of the poor (and of the clerisy and the bourgeoisie). I want the poor to become bourgeois in spirit, and to admire the bourgeoisie. The egregious Donald Trump is again a good example. Like a peasant admiring the King, the poor American worker in Toledo entranced by neo-fascism in fact admires the Rich Donald.

Yet American workers are commonly not envious, which distinguishes the American from the European or Asian or African poor. Americans, it has often been noted, are unusually bourgeois, and even poor Americans are. "Are non-elite, non-clerisy, low wage workers 
satisfied with what they have already received in the aftermath of the Bourgeois Deal"? No, of course they aren't. No one is ever satisfied. I should get more. You, too. But the edifying task is to persuade them to an ideology that enriches the world, not to inflame them with envy or anger, as progressivism or Trumpism does.

"This is the boldest of my claims, a fourth modification to create a viable Deal with low wage workers: engage with them philosophically. Not over personal values or way of life, but over the issues of our mutual welfare and what we owe others". Yes: edification. "Of course an ethicist like me would see a role for ethical explanation". Yes. I take the ethical justification to be justifying the ways of God to man, or more exactly justifying the ways of the Great Society to its people.

"I wonder, would McCloskey both convince the working class of this [Great Society of trade-tested betterment], and make them care about it"? I earnestly hope so. Taking on the Baker Critique, I promise in future to think more about reaching the working class. (By the way, I do not think the left clerisy reaches them, actually. The clerisy imagines solidarity, but only on the left's terms. Consider Leninism, and the leading role of the Party, staffed of course from the clerisy.) I have already, though, one simple thought about reaching the working class. It is something I learned long ago from the political theorist at the University of Iowa, John Nelson, namely, that the popular artists making movies and rock music are where ideology is formed. Professors of philosophy and economics and sociology and political science are swell. But the below-high-brow art is where the rubber meets the road, as we say in country music.

"What would it take for McCloskey to agree with the 'clerisy' that low wage workers have suffered grave losses of dignity in our currentday society"? It would take a history that did not in fact happen, the fairy-scary-tale history by Howard Zinn or Charles Sellers (which are suggestively parallel with Trumps' scare-mongering from the right), because low-wage workers were once utterly disdained. Look at blacks. And almost all your ancestors.

Similarly, Baker asks in a footnote, "is a 'peasant's view' of markets a realistic one (for the time) or not"? In a zero-sum society, it is realistic, but only roughly, since even with no growth there is a modest gain to be had from trade. But to get the big positive sum of the Great Enrichment, a factor of 30 or 100, we have to have an ideology supporting tradetested betterment. The ideology does not necessarily have to be in every 
detail correct, but it has to be an ideology nonetheless. As I said at one point,

Marxians call the acceptance of such betterment "false consciousness", a con job. Ideologies are indeed con jobs, whether good cons or bad. In psychiatry, false consciousness is called "lack of insight". If you as the patient don't agree with the psychiatrist's ideology you are said to exhibit such a lack. But unless the masses in a democracy accept betterment they can be led by populists or Bolsheviks or fascists to rise up and kill the goose. That's another con job, with worse consequences. Killing the golden goose has never been good for the poor (p. 575).

S.M. Amadae's point is exactly mine (and so I will merely register our disagreements), namely, to resist what she calls neo-liberalism, namely, the game theory that Gerry Gaus for example favors, and to revive the classical liberalism of Smith and Mill that "encompasses ethical commitment", as she puts it. "The neoliberal institutionalists", such as Gaus and sometimes Mokyr, she writes "concentrate on incentives to the exclusion of ethical reasons for action".

She is of the left. I was once, too. Now I wander uneasily between left and right-in the "dialectic" she helpfully attributes to me. Amadae in effect wants me to declare whether or not I admire Nordic social democracy. I do, at any rate for Nordics and Minnesotans. I'm not so sure it can be implemented without crippling corruption in Italy or Illinois. No reasonable Italian or Illinoisan wants to give her rulers more money and power in order to go on pretending to do lovely things for poor people while Swiss bank accounts and Wisconsin hunting lodges grow fat.

"I ask McCloskey to take a position on whether ideals should be accompanied with a commitment to a minimal safety net, to ensure the inclusion of the least well-off in the opportunities for development". Glad you asked. The answer is, yes. I am, as I said often in the book, a christian libertarian, or a bleeding-heart classical liberal, or a sisterly enthusiast for free and dignified commoners. Or if you wish, and Amadae does, I am a "dialectical libertarian". I argue in detail, however, that by far the best safety net is vigorous economic growth, which enriches laborers by much more than any transfer or trade union can. And in any case an enrichment, such as in the notably capitalist and 
innovative Swedish economy after the liberalization of the 1850s, makes possible the taxes to pay for a welfare state. That is, it does unless Italian or Illinoisan politicians get to the money first.

It is clear that I need to read Amadae, and I undertake to do so. But I detect in her a (justifiable) annoyance that I haven't done so yet.

On the other hand, it is pretty clear she hasn't read the other books in the trilogy, since many of her points are anticipated or answered by them. When Amadae notes in support of the proposition she and I share, that "non-consequentialist forms of action, including rulefollowing, commitment and promising, loyalty and trust, depend on reasons for action independent from satisfying preferences" she cites Sen (1985), Hausman (2012), Heath (2011), but not McCloskey (2006), or in briefer form McCloskey (1994a), which were devoted to exactly that proposition, through a virtue-ethical approach more philosophically nuanced than Sen's "commitment". She says that I was "not engaging in the intricacies of the contemporary debates on this topic", which she would have known to be mistaken if she had read The bourgeois virtues-unless indeed, as I suspect is the case in her mind, the "intricacies" are to be confined to a narrow group of economic methodologists devoted to certain routine games in analytic philosophy. (And if she had read Knowledge and persuasion in economics (1994b) she would know my take on the routine games.) In a puzzling sentence she complains about my alleged "literary dismissal of surgically honing in on the key points of contemporary debate in favor of recounting the history of capitalism". It seems to irritate her that I use evidence from literature and from history, as though routine analytic philosophy is the only way to get at "the key points". I do not think it is. There are many routes to edification.

Further, she makes the same Weberian mistake that Gaus makes in attributing to me the view that the bourgeoisie just got better, exhibiting "the correct virtues of temperance and prudence". No. The bourgeoisie was always thus. It is what one means by a successful merchant in, say, ancient Rome or in present-day New Delhi. What did change was (what she in the same sentence mixes with the Weberian notion) the society's "commitment to human dignity and liberty". In a word, liberalism. ${ }^{4}$

\footnotetext{
${ }^{4}$ EJPE's NotE: The author, S.M. Amadae, modified her reply in proof and in consequence the first quote of this paragraph has changed into: "the correct virtues of temperance, prudence, and justice". The second quote has been deleted.
} 
Maybe it would have been good to suggest to the reviewers here that they read, or at any rate buy, Bourgeois dignity, which gives most of the economics, and also The bourgeois virtues, which gives most of the ethical philosophy. But I concede that 700 pages is quite a lot, and 1,700 verges on being unforgivable. (Amadae complains that I do not cite Habermas. She must have missed pages 395 and 555, not to speak of The bourgeois virtues, and my writings in the 1980s and 1990s on rhetoric making great use of the honored Jürgen, who is usually unread, because unreadable. But, alas, that's many more pages than one can reasonably expect a reviewer to read.)

Again, Amadae doesn't think I present "a rigorously presented case", ${ }^{5}$ which suggests that she has no knowledge of Bourgeois dignity: why economics can't explain the modern world-though it could also be, I fear, that by "rigorously presented" she again means routine analytic philosophy, not a serious engagement with all the edifying arguments and evidence. She wishes "McCloskey had either acknowledged that capitalism is only statistically better on average, and that some people pay the price for economic growth". Such talk is that of a political theorist who is not actually open to "mere" quantitative or economic thinking. "Only statistically better on average" means, as I rigorously show throughout, upwards of a 10,000 percent increase per capita, 1800 to the present, which is of such a magnitude as to make it nearly impossible to find "some people" who "pay the price of economic growth". At 100 percent, sure. At 3,000 percent, unlikely. At 10,000 percent, well, you see what I mean.

Therefore, of course the Great Enrichment has been "inclusive". Only someone who disdains an engineer's sense of magnitude would think otherwise. The entire income distribution leapt out so dramatically to the right that it is virtually impossible to find someone in, say, Finland who is shorter in height or years of life than her ancestors taken as a group, or more subject to starvation than Finns in 1866-1868, or less literate than Finns before the Compulsory School Attendance Act of 1921. And to think economically, the traditional farmers, say, whose land is bought out by developers, share in the enrichment. And the loss to harness-makers that comes from the invention of the automobile is massively offset by the gain to others, and even to the harness-makers now riding about in their Ford cars. "Merely" quantitative growth made

\footnotetext{
${ }^{5}$ EJPE'S NoTE: The author, S.M. Amadae, modified her reply in proof and in consequence this quote has changed into: "comprehensive numeric defense".
} 
virtually all Finns, whether farmers or harness makers, massively healthier, less subject to famine, and 99.98 percent literate.

But I suspect that Amadae will not be easily moved from her apparent acceptance of the conventions of leftish history. She wants me to reply to Marxist history and economics. Doing so in some detail was in fact one of the main themes of the trilogy. ${ }^{6}$ As was pointed out as early as Hayek (1954), the left is convinced that there must have been some original sin to explain 'capitalism' (the fact of which, by the way, the British did not 'invent'). So does Amadae. Such a history is defective, as the trilogy shows.

In the Marxist, or at any rate Marxoid, fashion, for example, she criticizes me harshly for allegedly ignoring the slave trade, which criticism suggests again that she is not familiar with the other books in the trilogy. She is confident that "the gross injustices experienced by enslaved African-Americans [...] contributed to the hockey blade's meteoric ascent (Sherwood 2007; Baptist 2014)". I know that many people such as Sherwood and Baptist argue that slavery was crucial. I also know that it makes people feel virtuous to rail against gross injustice, as slavery certainly was (or at any rate so we came to think it was after many bourgeois theorists such as Wilberforce instructed us). But the belief that slavery was a crucial cause of the Great Enrichment, despite the noble embodiment of the belief in Lincoln's Second Inaugural, say, is implausible as economics or as history. For one thing, slavery was ancient but modern economic growth was, well, modern. For another, slavery was not necessary for Western growth, as you can see for example in the acceleration of growth after slavery was abolished. For still another, it was a bourgeois 'capitalist' society, especially in Britain and in the Northern United States, that worked to abolish "legalized slavery [under which] some individuals profit while others shoulder the burden".

Again, she criticizes me for not dealing with inequality. Unhappily, the criticism is still another fashionable and un-self-critical leftism on her part. In fact I deal with inequality massively in the book, and in more pointed form in a long review of Piketty's book in the pages of this journal (McCloskey 2014b).

Amadae leaves off leftish clichés, though, and really gets going at the very end, in pages I much admire beginning "While McCloskey's argument may be incomplete for not fully defining or explaining

\footnotetext{
${ }^{6}$ A short form is McCloskey (2016b).
} 
'liberty', or human dignity" (neither is correct, but I am using the phrase merely as a passage-marker). She correctly notes that Smith had two micro principles, one being 'prudence' and the other the 'impartial spectator' (not the "impartial judge", as Amadae remembers the phrase), both having macro consequences. I said this, at some length, calling it "Smith's other invisible hand, the social one as against the economic. We become polite members of our society by interacting on the social stage-note the word, 'inter-acting"' (2016a, 204). Amadae views me therefore as proposing "a dialectical structure that places both ethics and tangible self-betterment on a complementary footing", which suggestion I gratefully accept.

\section{$\S$}

And finally to my beloved vriendje, Joel Mokyr. As you might not infer from his sometimes overly sharp comments here, Joel and I agree on an immense amount, substantively and methodologically (if not in every detail politically), in economics and in history and in economic history. I started focusing on the central question of social science-why are we so much richer than our ancestors? - a decade after he did. He has taught me massively. Without his books I could not have written mine.

And he and I with a very few others stand together against idea-less accounts, from Marx to freakonomics. As he writes,

Professor McCloskey cites me (p. 511) as having written that 'economic change depends, more than most economists think, on what people believe'. That message [the opening sentence of his 2010 book], obvious as it may sound, needs to be stated and restated, to rid ourselves of the relics of historical materialism.

Joel and I deeply agree with Goldstone and Jacob and, in some of his moods, Eric Jones-who together constitute a tiny ideational school of economic history just emerging from the unreflective materialism of our less mature years-that ideas were the steam power of the Great Enrichment.

What Joel and I do not exactly agree on is whether steam power was its steam power. That is, Joel believes that Science was important early, as for example in making possible atmospheric steam engines once the Scientists had shown that air had weight, and vacuums created by condensing steam could therefore draw a piston in. I believe that if we 
do the accounting correctly-admitting that is hasn't literally been done yet, by weighting innovations by their economic importance instead of merely listing them and expressing dazzled admiration-Science does not have much of an economic impact until after about 1900. Most of our riches until then, and quite a few of them down to the present, are the result of technology and technologists, the 'tinkerers' you hear so much about (Peg Jacob detests the word, but on the other hand admires the engineers for doing it).

I use the argumentative capitalization on 'Science' because I want to discourage you from using another and dangerous word, much on the popular tongue, 'science-and-technology'. It is in effect a German portmanteau word, used by Scientists to claim credit for technology, much of which is only remotely connected with their work. High energy physicists at CERN, who should be embarrassed that physics has stagnated for some fifty years, (and who therefore have to call most of matter and energy 'dark'), use science-and-technology to keep the billions flowing.' (I do not exempt my own beloved science of economics from such hostile characterization, though the amount spent on it is three orders of magnitude below than what is spent on physics or astronomy.) The STEM fields include in the ' $M$ ' the mathematicians chiefly interested in Greek-style proofs in number theory or algebraic topology with essentially no applications to engineering, much less to technology, and much, much less to technologies with a large role in human welfare.

I am not 'against Science'. Let me repeat that. I could hardly be 'against Science', and certainly not against plain old science. Joel and I are both scientists by anything but the peculiarly English definition of the past century and a half, during which sense $5 b$ in the Oxford English dictionary became, bizarrely, "the usual sense in ordinary usage", that is, defined as confined to physical and biological 'science'. Earlier in English, and still now in every other language in the world, the science word means "systematic inquiry", as against, say, casual journalism or unsupported opinion. Thus Joel and I delight in the Dutch word geesteswetenschappen, 'spirit sciences', which British people call 'arts subjects' and we American speakers call 'humanities'. Mathematical number theory, for example, as a part of geesteswetenschap, is endlessly fascinating, though less useful than most poetry.

${ }^{7}$ For which see Horgan 1996. 
I am merely, as a citizen, against the arrogance of a Science demanding support even if it is useless and illiberal. And I am merely as an economic scientist against Science's claims to account for the whole of the enriched modern world of trade-tested betterment. 'Science-andtechnology' again.

Or to make a slightly different economic point, I am noting, and did also note in the book, that Science itself would have little of value to show for ordinary human welfare if it had not come to be financed massively during the first couple of centuries of the Great Enrichment, sending German boys to study chemistry at the University of Berlin and American boys to study genetics at Iowa State University, and then even the girls. And the first couple of centuries, down to around 1900, or on a really large scale (penicillin, jet engines) down to around 1950, were attributable mainly to technology, not to the Baconian High Science over which Joel so affectingly swoons. Without doubt, as he writes, "German chemists in Giessen developed organic chemistry with enormous effects on industry and agriculture". But when were the "enormous effects"? Unless you think of van Gogh's use of "synthetic lake of eosin color", known as geranium lake, is an "enormous effect", the big effect was not until Haber and artificial fertilizer (and poisonous gas), which indeed was not used enormously until well into the 20th century. As I said.

Joel claims that "McCloskey simply dismisses the impact of science and the scientific revolution as immaterial and of little practical value until 'the 1960s [when] we wanted to navigate our way to the moon'”. Here's what I actually said:

Francis Bacon, in Mokyr's account, was John the Baptist to the various messiahs of Science, above all Newton. But the messiahs, and even Newton, performed few practical miracles until late in the game-when, for example, in the 1960s we wanted to navigate our way to the moon. The earlier, technologically relevant miracles happened at the lower level among ordinary religionists of a liberal society and therefore of a liberated technology. The Bourgeois Revaluation liberated and dignified ordinary people making betterments (2016a, 506).

It makes his case easier to portray me as some sort of maniak who dismisses electricity, radio, airplanes, artificial fertilizer, catalytic cracking, dye-stuffs, and antibiotics, all of which had heavy inputs from the highest of High Science. I actually said-and I've said it repeatedly to him, in print and in personal correspondence, and indeed in response to 
an earlier draft of his comments here, which he forthrightly shared with me-that I reckoned that Science started to matter to a considerable part of the economy, as I said, around 1900. That's not the time of the moonshots (though admittedly the shots were the biggest ever application of navigation by Newton's laws of motion). We can find out whether this is true by examining the facts, and do not need to appeal to suggestions that one or the other of us is a maniak.

Joel then falls in with the usual indignant defenses of Science, and declares, as though I made such a case, that "the dismissal of any role of formal and codified knowledge in advancing technology and the discourse that led to the triumph of the Baconian program in the West is simply unsupportable". (I thought perhaps he would next accuse me of believing in fairies and astrology, but he refrained.) I never "dismissed any role" for Science in making us richer. I say to him again: Lieverd, what a charge to make!

Joel often in the piece lets his rhetoric get heated in this way for no reason-except the reason, one suspects worryingly, that he is angry that I do not join with sufficiently piety the modern worship of Science. He says for example that I "leave out Joseph Priestley, the discoverer of oxygen, the inventor of carbonated drinks and pencil erasers". For one thing, I didn't (2016a, 287). For another, carbonated drinks and pencil erasers make the point against Joel's it's-mainly-Science view, namely, that only in a few corners of the economy did Science much matter until 1900.

But of course Joel, as a great economic historian and a great student of the history of technology, does know better. And so he immediately takes it all back, writing,

McCloskey is of course correct in pointing out that at first the tangible achievements of science were modest. Many scientific areas in which progress would yield its highest fruits in the Great Enrichment turned out to be much messier and more complex than expected. The hopes that eighteenth-century post-Newton scientists had to Newtonize chemistry, medicine, biology, and agricultural science were all disappointed in the short run.

I couldn't have, and didn't, say it better myself, nor did I know the excellent quotation he gives from Samuel Johnson illustrating the point.

Yet he goes off the rails once more: "an economist will remain dissatisfied: what is the true driver in this model? Why and how did the discourse change and the 'Bourgeois Revaluation' prevail in 
Northwestern Europe in the sixteenth and seventeenth century? Why not elsewhere, or at some other time"? I reply, "Good Lord, gekkie, I give masses of evidence answering the very questions. More broadly, the brief quotations you give of the answers I give are grossly unrepresentative of my argument. My argument is backed by hundreds of pages of documentation of one sort or another". The way Joel presents it suggests that I make silly but briefly summarizable claims that are unsustainable and unsubstantiated. My actual arguments are unorthodox, true, and seem from the point of view of the orthodoxy of capital accumulation or institutional accumulation to be crazy. Joel takes rhetorical advantage of orthodox opinion. (It's a pretty cheap trick, dearie.) He says, in effect, 'Everyone knows that [such and such a scientifically dubious claim about economic history, which he himself admits is dubious, or has himself shown to be dubious] is so. Isn't it shocking that McCloskey denies it?!'

I have elsewhere seen Joel admit that the 1830s might be the time by which Science really started to matter much to the economy. I would say the 1890s. It's not a great difference, considering that both of us deny the material causes everyone else thinks are crucial. The way to settle the rather minor scientific disagreement between us, then, is to measure. I've suggested to Joel in correspondence how one might go about it, using random samples of economic activity and then carefully thinking through just how much the insights of Science mattered to each. But in any case (a point that the economic historian Robert Margo has made) economists and economic historians after Robert Fogel's calculation of the social saving from railways cannot leave off their labors by waving at Great Men or Great Inventions or Great Government Intervention and declaring angrily to any doubter that the economy was obviously "based" on them. The "based" metaphor is indeed a metaphor, and needs to be cashed in with calculations about substitutes. That's economics. Otherwise one is led to say that the economy is "based" on carbonated drinks and pencil erasers, because everyone uses them: imagine if our carbonated drinks and erasers were suddenly taken away! Quel désastre!

Joel says that the Bourgeois Revaluation was important. I invite him to say so forcefully, and to acknowledge that the Scientific Revolution on which he focuses was itself made wide and fruitful by a liberalism that allowed people to have a go--ordinary people, not the cliché of "the 
rise of the bourgeoisie", nor even his scientific or technical elite that mysterious "arises" without political or social support.

In short, we have substantial agreement here. Everyone agrees that ideas mattered, greatly, and in particular the liberal idea making for the technical and scientific and institutional ideas.

The agreement signals a novel scientific advance-or it would be novel, to tell the truth, if it were not in fact the merest commonplace of 18th century liberal thought. The thoughts of the clerisy in the 19th century, by contrast, were novel and became commonplaces, but not good. Nationalism and socialism were chief among them (and if you like these, try national socialism), but they ranged from scientific racism to geographic determinism and the rule of experts. Yet the Great Enrichment itself proved scientifically that, say, both social Darwinism and economic Marxism were mistaken. The genetically inferior races and classes and ethnicities, contrary to Ernst Haeckel, proved not to be so. They proved to be creative. The exploited proletariat, contrary to Marx, was not immiserized. It was enriched. In the enthusiasm for the materialist but deeply erroneous pseudo-discoveries of the nineteenth century much of the clerisy mislaid its earlier ideational commitment to a free and dignified common people. It forgot the main, and the one scientifically proven, social discovery of the nineteenth century-itself in accord with a Romanticism mischievous in other ways-that ordinary men and women do not need to be directed from above, and when honored and left alone become immensely creative.

"I contain multitudes", sang the democratic, American poet Walt Whitman. And he did.

\section{REFERENCES}

Baptist, Edward. 2014. The half has never been told: slavery and the making of American capitalism. New York: Basic Books.

Cartwright, Nancy, and Jeremy Hardie. 2012. Evidence-based policy: a practical guide to doing it better. Oxford: Oxford University Press.

Findlay, Ronald, and Kevin H. O'Rourke. 2007. Power and plenty: trade, war, and the world economy in the second millennium. Princeton: Princeton University Press. 
Greif, Avner. 2006. Institutions and the path to the modern economy: Lessons from medieval trade. Cambridge: Cambridge University Press.

Hausman, Daniel M. 2012. Preference, value, choice, and welfare. Cambridge: Cambridge University Press.

Hayek, Friedrich. 1954. Capitalism and the historians. Chicago: University of Chicago Press.

Heath, Joseph. 2011. Following the rules: practical reason and deontic constraint. Oxford: Oxford University Press.

Horgan, John. 1996. The end of science: facing the limits of science in the twilight of the scientific age. New York: Broadway Books.

McCloskey, Deirdre Nansen. 1994a. Bourgeois virtue. American Scholar, 63 (2): 177191.

McCloskey, Deirdre Nansen. 1994b. Knowledge and persuasion in economics. Cambridge: Cambridge University Press.

McCloskey, Deirdre Nansen. 2006. The bourgeois virtues: ethics for an age of commerce. Chicago: University of Chicago Press.

McCloskey, Deirdre Nansen. 2013. A neo-institutionalism of measurement, without measurement: A comment on Douglas Allen's the institutional revolution. Journal of Austrian Economics, 26 (4): 262-373.

McCloskey, Deirdre Nansen. 2014a. Getting beyond neo-institutionalism: Virgil Storr's culture of markets. Review of Austrian Economics, 27 (4): 463-472.

McCloskey, Deirdre Nansen. 2014b. Measured, unmeasured, mismeasured, and unjustified pessimism: a review essay of Thomas Piketty's Capital in the twentyfirst century. Erasmus Journal for Philosophy and Economics, 7 (2): 73-115.

McCloskey, Deirdre Nansen. 2016a. Bourgeois equality: how ideas, not capital or Institutions, Enriched the World. Chicago: University of Chicago Press.

McCloskey, Deirdre Nansen. 2016b. Economic liberty as anti-flourishing: Marx and especially his followers. In Michael R. Strain and Stan A. Veuger, eds. Economic liberty and human flourishing: perspectives from political philosophy. Washington, DC: American Enterprise Institute, 129-149.

McCloskey, Deirdre Nansen. 2016c. The humanities are scientific: a reply to the defenses of economic neo-institutionalism. Journal of Institutional Economics, 12 (1): $63-78$.

McCloskey, Deirdre Nansen. 2016d. Max U versus humanomics: a critique of neoinstitutionalism. Journal of Institutional Economics, 12 (1): 1-27.

Plantinga, Alvin. 2000. Warranted Christian belief. New York: Oxford University Press.

Sen, Amartya. 1985. Goals, commitment, and identity. Journal of Law, Economics, and Organization, 1 (2): 341-355.

Sherwood, Marika. 2007. After abolition: Britain and the slave trade since 1807. London: I.B.Tauris.

Smith, Adam. 1978 [1762-1766]. Lectures on jurisprudence, Glasgow edition, eds. R. L. Meek, D. D. Raphael, and P. G. Stein. Oxford: Oxford University Press.

Smith, Adam. 1981 [1776]. An inquiry into the nature and causes of the wealth of nations, Glasgow edition, eds. R. H. Campbell, A. S. Skinner, and W. B. Todd, 2 vols. Indianapolis: Liberty Classics.

White, James Boyd. 1984. When words lose their meaning: constitutions and reconstitutions of language, character, and community. Chicago: University of Chicago Press. 
Deirdre Nansen McCloskey is professor emerita of economics, history, English, and communication, and adjunct professor emerita of philosophy and classics, University of Illinois at Chicago.

Contact e-mail: <deirdre2@uic.edu> Website: www.deirdremccloskey.org 